\title{
Penentuan Fungsi Linear yang Ideal Pada Model Ekonomi Fungsi Penawaran
}

\author{
Tonaas Kabul Wangkok Yohanis Marentek ${ }^{(1)}$ Mohamad Trio Febryiantoro $^{(2)}$ \\ Universitas Universal \\ * Korespondensi: tonaasmmarentek@uvers.ac.id
}

Diserahkan: 10 Pebruari 2018, Direvisi: 2 Maret 2018, Diterima: 2 April 2018

\begin{abstract}
The economic phenomenon is complex because the relationship between economic variables in the real world is very complex. The phenomenon becomes an economic model by simplifying. Bidding function is one of the simplified economic phenomenon into a mathematical economic model that is by selecting two important economic variables only the variable price and variable amount of goods a product offered. The formation of the supply function of the given bid data set using three mathematical methods ie the dualcoordinate method, the slope-coordinate method and the least squares method in a simple linear regression analysis are obtained by eleven types of bidding function in the form of a linear equation. The function that is formed is a form of linear equations in accordance with the rules and economic theory of supply functions. Then, by conducting a market equilibrium analysis, there are seven ideal supply functions of the eleven functions formed. The ideal of the bid function is determined by an ideal assumed demand function. In addition, model validation in this study by determining the ideal of a supply function based on market equilibrium analysis.
\end{abstract}

Keywords: Economic model, Offer function, Demand function, market equilibrium

abstrak

Fenomena ekonomi yang kompleks karena hubungan antar variabel-variabel ekonomi dalam dunia nyata sangatlah kompleks. Fenomena tersebut menjadi sebuah model ekonomi dengan melakukan penyederhanaan. Fungsi penawaran merupakan salah satu fenomena ekonomi yang disederhanakan menjadi sebuah model ekonomi matematis yaitu dengan memilih dua variabel ekonomi yang penting saja yaitu variabel harga dan variabel jumlah barang suatu produk yang ditawarkan. Pembentukan fungsi penawaran dari kumpulan data penawaran yang diberikan yang menggunakan tiga metode matematis yaitu metode dwikoordinat, metode koordinat-lereng dan metode kuadrat terkecil dalam analisis regresi linear sederhana diperoleh sebelas jenis fungsi penawaran yang berbentuk suatu persamaan linear. Fungsi yang terbentuk tersebut adalah bentuk persamaan linear yang sesuai dengan kaidah serta teori ekonomi fungsi penawaran. Kemudian dengan melakukan analisis kesetimbangan pasar diperoleh tujuh fungsi penawaran yang ideal dari sebelas fungsi yang terbentuk. Keidealan fungsi penawaran tersebut ditentukan dengan diberikan sebuah fungsi permintaan yang diasumsikan ideal. Selain itu, validasi model pada penelitian ini dengan menentukan keidealan suatu fungsi penawaran yang berdasarkan analisis keetimbangan pasar.

Kata Kunci : Model ekonomi, Fungsi penawaran, Fungsi permintaan, kesetimbangan pasar

\section{A. PENDAhULUAN}

Ilmu ekonomi dan bisnis adalah ilmu yang bersifat semi eksakta. Untuk mempelajari dan memahami ilmu ekonomi diperlukan suatu analisis yang bersifak kualitatif dan kuantitatif. Analisis yang bersifat kuantitatif ini dalam ekonomi dan bisnis harus menggunakan matematika sebagai instrumen atau alat bantu. Sehingga untuk mempelajari ilmu ekonomi dan bisnis secara baik harus mempelajari dan memahami ilmu Matematika Ekonomi dan Bisnis. Matematika ekonomi dan bisnis merupakan bagian dari matematika terapan dan matematika terapan merupakan bagian dari matematika murni. Matematika murni apabila diaplikasikan dengan berbagai ilmu 
ekonomi, juga bisa membentuk model perencanaan seperti pembelian, penjualan, bahkan ilmu audit untuk keuangan pubik (Purbowati, R., \& Utomo, L. P. ,2016)

Topik-topik matematika murni yang sering digunakan dalam matematika ekonomi dan bisnis adalah Fungsi, Kalkulus, Deret dan Matriks. Topik-topik tersebut digunakan untuk membangun sebuah model ekonomi dari suatu teori ekonomi yang berbentuk kualitatif ataupun deskriptif.

Suatu teori ekonomi: "Jika harga suatu barang/jasa yang ditawarkan produsen (diminta oleh konsumen) naik (turun), maka jumlah barang/jasa yang tawarkan atau diminta dari barang tersebut akan berkurang (bertambah)". Teori ekonomi tersebut mengasumsikan bahwa variabel-variabel lain yang mempengaruhi jumlah barang/jasa yang ditawarkan atau diminta tersebut adalah konstan. Kenyataannya, dalam dunia nyata perekonomian hubungan antara variabel-variabel ekonomi yang satu dengan yang lainnya adalah sangatlah kompleks. Sehingga, untuk memudahkan hubungan antar variabel-variabel dalam ekonomi adalah dengan memilih variabel-variabel yang sesuai dengan kaidah ekonomi.

Penyederhanaan variabel dan hubungan antar variabel-variabel ekonomi disebut model ekonomi. Model ekonomi dapat berbentuk model matematika dan non matematika. Model ekonomi yang berbentuk matematika terdiri dari satu atau sekumpulan persamaan matematika. Karena model ekonomi merupakan penyederhanaan hubungan antar variabel maka model ekonomi tersebut berupa fungsi. Model ekonomi yang berbentuk suatu fungsi sering digunakan oleh para ahli ekonomi dalam memecahkan masalah-masalah ekonomi dalam hal peramalan ataupun pendugaan juga dikarenakan banyak masalah dalam bidang ekonomi dapat disederhanakan menjadi sebuah persamaan matematika yang bisa berbentuk sebuah fungsi linear ataupun nonlinear. Fungsi permintaan dan Fungsi Penawaran adalah bentuk penyederhanaan masalah dalam bidang ekonomi. Penyederhanaan tersebut dinyatakan dalam bentuk model matematika. Salah satu bentuk model matematika adalah sebuah persamaan yang berbentuk fungsi linear.

Pembentukan model ekonomi fungsi penawaran yang berbentuk persamaan linear dengan mempertimbangkan masalah penaksiran nilai parameter maupun penentuan variabel yang sesuai dengan teori ekonomi. Sehingga, dalam membentuk sebuah fungsi linear harus berlandaskan pada prinsip serta kaidah ilmu matematika dan ilmu ekonomi. Dalam matematika, fungsi linear adalah suatu fungsi yang sederhana yang bentuk persamaannya terdiri dari koofisien dan konstanta (parameter) serta terdiri dari beberapa variabel bebas dan variabel takbebas yang berderajat atau mempunyai pangkat satu.Dengan memanfaatkan prinsip-prinsip matematika maka model ekonomi tersebut dapat kita bentuk jika terdapat data-data penawaran ataupun data permintaan dengan menggunakan metode-metode matematika dan statistik yaitu metode Dwi-Koordinat, Koordinat-Gradien/Lereng dan metode kuadrat terkecil dalam regresi linear statistika.

Penelitian ini bertujuan untuk mengetahui lebih dalam tentang fungsi penawaran dengan menggunakan metode matematis. Diharapkan, hasil dari penelitian ini akan menjadi referensi ilmu yang baru khususnya tentang matematika ekonomi. Pada tulisan ini, akan dibentuk model ekonomi fungsi penawaran yang berbentuk sebuah persamaan garis lurus atau persamaan linear dengan menggunakan metode-metode matematika dan statistika dan berlandaskan pada teori serta hukum dalam ilmu ekonomi. Selanjutnya, model tersebut akan divalidasi dengan menentukan keidealannya yaitu dengan melakukan analisis kesetimbangan pasar. 


\section{B. LANDASASAN TEORI Model Ekonomi}

Dalam dunia nyata khususnya dalam bidang ekonomi terdapat berbagai persoalan yang muncul dari fenomena ekonomi yang kompleks. Sehingga untuk menjawab persoalan tersebut diperlukan solusi yang ideal, solusi tersebut sulit diperoleh jika persoalan-persoalan tersebut muncul dari sebuah fenomena ekonomi yang kompleks yang perlu penyederhanaan. Fenomena tersebut menjadi kompleks karena hubungan yang terjadi antara variabel-variabel ekonomi tersebut sangat kompleks. Penyederhanaan fenomena tersebut adalah dengan memilih variabel-variabel yang penting saja dengan mengganggap variabel yang lain bernilai konstan. Sehingga penyederhanaan seuah fenomena ekonomi ekonomi yang kompleks tersebut dapat disederhanakan menjadi sebuah model ekonomi karena model ekonomimerupakan suatu kerangka kasar dari sebuah fenomena ekonomi yang sesungguhnya dan yang terjadi di dunia nyata. Untuk dapat mewakili fenomena ekonomi maka model ekonomi tersebut dapat berbentuk sebuah model ekonomi matematika dan model ekonomi non matematika. Model ekonomi yang berbentuk non matematis merupakan sebuah pernyataan yang bisa terdiri dari satu atau lebih kalimat pernyataan, dimana setiap kalimat tersebut menyatakan secara eksplisit hubungan kualitatif antar variabel. Sedangkan model ekonomi yang berbentuk matematis adalah sebuah model ekonomi yang terdiri dari satu atau sekumpulan persamaan matematis, persamaan tersebut terdiri dari variabel, konstanta, koefisien dan/atau parameter dimana terdapat hubungan fungsional yang bersifat kuantitatif antar variabel. Sehingga bisa dikatakan juga bahwa model ekonomi yang berbentuk matematis juga merupakan suatu penyederhanaan dari sebuah model ekonomi non matematis yaitu penyederhanaan hubungan antar variabel dari bentuk kualitatif yang abstrak menjadi suatu bentuk kuantitatif. Salah satu bentuk model ekonomi yang berbentuk matematis adalah fungsi penawaran, fungsi permintaan dimana telah dilakukan penyederhaan hubungan fungsional variabel-variabel ekonomi yang berpengaruh, model ekonomi tersebut berbentuk suatu persamaan matematika yang linear ataupun non linear. (Kalangi, 2015).

Dalam Dumairi (2015), fungsi linear adalah suatu fungsi yang sangat sering digunakan oleh ahli ekonomi dan bisnis dalam menganalisis dan memecahkan masalahmasalah ekonomi, dikarenakan kebanyakan masalah ekonomi dan bisnis dapat disederhanakan atau diterjemahkan kedalam model yang berbentuk linear. Penerapan fungsi linear dalam teori ekonomi makro adalah dalam fungsi pajak, fungsi investasi, fungsi ekspor-impor, pendapatan nasional serta analisis IS-LM. Sedangkan dalam ekonomi mikro fungsi linear dapat diterapkan kedalam model ekonomi yaitu model ekonomi fungsi penawaran dan fungsi permintaan.

\section{Model Ekonomi Fungsi Permintaan}

Teori permintaan menyatakan "fungsi permintaan menunjukan hubungan antara jumlah produk yang diminta oleh konsumen dengan variabel-variabel lain yang mempengaruhinya pada satu periode tertentu". Variabel-variabel ini bila ditelusuri dalam perekonomian yang sesungguhnya sangat banyak jumlahnya. Variabel utama yaitu: (1) Harga barang itu sendiri, (2) Pendapatan konsumen, (3) Harga barang lain yang saling berhubungan, (4) Harga lain yang diharapkan pada periode mendatang, (5) Selera konsumen dan (6) Belanja untuk iklan.Sehingga penyederhanaan hubungan variabel tersebut menjadi fungsi linear model ekonomi permintaan sebagai berikut:

$$
Q_{d x, t}=f\left(P_{x, t}, P_{y, t}, Y_{t}, P_{x, t+1}^{e}, S_{t}, A_{t}\right)
$$


dengan

$Q_{d x, t}=$ Jumlah produk $\mathrm{X}$ yang dibeli/diminta oleh konsumen dalam periode $\mathrm{t}$

$P_{x, t}=$ Harga produk $\mathrm{X}$ pada periode $\mathrm{t}$

$P_{y, t}=$ Harga produk $\mathrm{Y}$ pada periode $\mathrm{t}$

$Y_{t}=$ Pendapatan konsumen dalam periode $\mathrm{t}$

$P_{x, t+1}^{e}=$ Harga produk X yang diharapkan dalam periode mendatang, $\mathrm{t}+1$

$S_{t}=$ selera dari konsumen pada periode $\mathrm{t}$

$A_{t}=$ Belanja periklanan pada periode $\mathrm{t}$

Hubungan fungsional dalam teori ekonomi antara variabel jumlah produk yang diminta oleh konsumen dengan kelima variabel bebas lain (hal-hal lain dianggap konstan) adalah :

$Q_{d x, t}$ mempunyai hubungan yang negatif dengan $P_{x, t}$

$Q_{d x, t}$ mempunyai hubungan yang positif atau negatif dengan $P_{y, t}$

$Q_{d x, t}$ mempunyai hubungan yang positif atau negatif dengan $\mathrm{Y}_{t}$

$Q_{d x, t}$ mempunyai hubungan yang positif dengan $P_{x, t+1}^{e}$

$Q_{d x, t}$ mempunyai hubungan yang positif $\mathrm{S}_{t}$

$Q_{d x, t}$ mempunyai hubungan yang positif $\mathrm{A}_{t}$

Variabel harga produk adalah variabel yang paling penting sehingga dapat digunakan sebagai variabel bebas. Sedangkan kelima variabel bebas lainnya dianggap konstan. Oleh karena itu, fungsi permintaan dapat ditulis dalam bentuk yang lebih sederhana menjadi:

$$
Q_{x}=f\left(P_{x}\right)
$$

Persamaan (2) bila ditransformasikan kedalam bentuk fungsi linear menjadi persamaan (3) berikut dengan $Q_{x}=$ Jumlah barang $\mathrm{X}$ yang diminta, $P_{x}=$ Harga produk $\mathrm{X}$ dan serta nilai a dan $\mathrm{b}$ adalah parameter adalah

$$
Q_{x}=a+b P_{x}
$$

Dua hal penting fungsi permintaan yang merupakan kaidah ekonomi. Yaitu:

1. Parameter $b$ bernilai negatif. Karena fungsi permintaan tunduk pada hukum permintaan, yaitu: "jika harga suatu produk naik (turun), maka jumlah produk yang diminta oleh konsumen akan berkurang (bertambah), dengan asumsi variabel lainnya adalah konstan."

2. Variabel bebas $P_{x}$ berpangkat 1. Dengan demikian secara matematis fungsi permintaan ini bila digambarkan kurvanya memiliki kemiringan (slope/gradien) yang negatif yaitu menurun dari kiri atas kekanan bawah, dan berbentuk garis lurus.

Sehingga secara geometri dalam bidang cartesius, kurva permintaan dapat digambarkan seperti Gambar 1 berikut. 


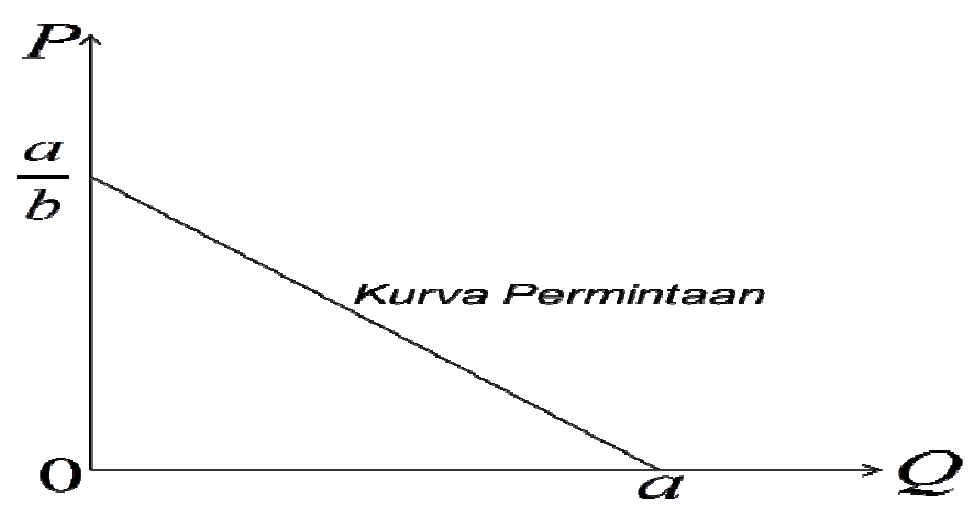

Gambar 1. Kurva Fungsi Permintaan (Kalangi, 2015)

\section{Model Ekonomi Fungsi Penawaran}

"Fungsi penawaran menunjukan hubungan antara jumlah produk yang ditawarkan oleh produsen untuk dijual dengan variabel-variabel lain yang mempengaruhinya pada satu periode tertentu". Variabel-variabel ini bila ditelusuri dalam perekonomian yang sesungguhnya sangat banyak jumlahnya. Variabel utama, yaitu: (1) harga produk tersebut, (2) tingkat teknologi yang tersedia, (3) harga dari factor-faktor produksi (input) yang digunakan, (4) harga produk lain yang berhubungan dengan produksi, (5) harapan para produsen terhadap harga produk tersebut dimasa datang. Secara matematis fungsi permintaan dapat ditulis menjadi:

$$
Q_{s x, t}=f\left(P_{x, t}, T_{t}, P_{F, t}, P_{R, t}, P_{x, t+1}^{e}\right)
$$

dengan :

$Q_{s x, t}=$ Jumlah produk $\mathrm{X}$ yang ditawarkan oleh produsen dalam periode $\mathrm{t}$

$P_{x, t}=$ Harga produk $\mathrm{X}$ pada periode $\mathrm{t}$

$P_{F, t}=$ Harga faktor-faktor produksi dalam periode $\mathrm{t}$

$T_{t}=$ Teknologi yang tersedia dalam periode $\mathrm{t}$

$P_{R, t}=$ Harga produk lain yang berhubungan dalam periode $\mathrm{t}$

$\mathrm{P}_{x, t+1}^{e}=$ Harapan produsen terhadap harga produk dalam periode $\mathrm{t}+1$

Dalam teori ekonomi hubungan fungsional antara variabel jumlah produk yang diminta oleh konsumen dengan kelima variabel bebas (lainnya dianggap konstan) adalah berikut :

$Q_{s x, t}$ mempunyai hubungan yang positif dengan $P_{x, t}$

$Q_{s x, t}$ mempunyai hubungan yang negatif dengan $P_{F, t}$

$Q_{s x, t}$ mempunyai hubungan yang positif $\mathrm{T}_{t}$

$Q_{s x, t}$ mempunyai hubungan yang negatif dengan $P_{x, t+1}^{e}$

$Q_{s x, t}$ mempunyai hubungan yang positif $\mathrm{P}_{R, t}$

dari variabel-variabel bebas tersebut diatas, dapat disederhanakan lagi dengan menganggap variabel dari harga produk tersebut yang paling berpengaruh. Sedangkan keempat variabel yang lain dianggap konstan. Sehingga fungsi penawarannya menjadi :

$$
Q_{s x}=g\left(P_{x}\right)
$$


bila (2.5) ditransformasikan kedalam bentuk persamaan linear, maka bentuk umumnya adalah persamaan (2.6) dengan $Q_{x}=$ Jumlah produk X yang ditawarkan oleh produsen, $P_{x}=$ Harga produk $\mathrm{X}$ serta nilai a dan $\mathrm{b}$ adalah parameter.

$$
Q_{x}=a+b P_{x}
$$

Dua hal penting dalam fungsi penawaran memiliki dua hal yang penting. Yaitu :

1. Parameter $b$ bernilai positif. Karena fungsi penawaran tunduk pada hukum penawaran, yaitu : "jika harga suatu produk naik (turun), maka jumlah produk yang ditawarkan oleh produsen akan bertambah (berkurang), dengan asumsi variabel lainnya adalah konstan".

2. Variabel bebas $P_{x}$ berpangkat 1. Dengan demikian secara matematis fungsi penawaran ini bila digambarkan kurvanya akan memiliki kemiringan (slope/gradien) yang positif yaitu akan menaik dari kiri bawah kekanan atas.

Sehingga secara geometri dalam bidang cartesius, kurva permintaan dapat digambarkan seperti Gambar 2 berikut.

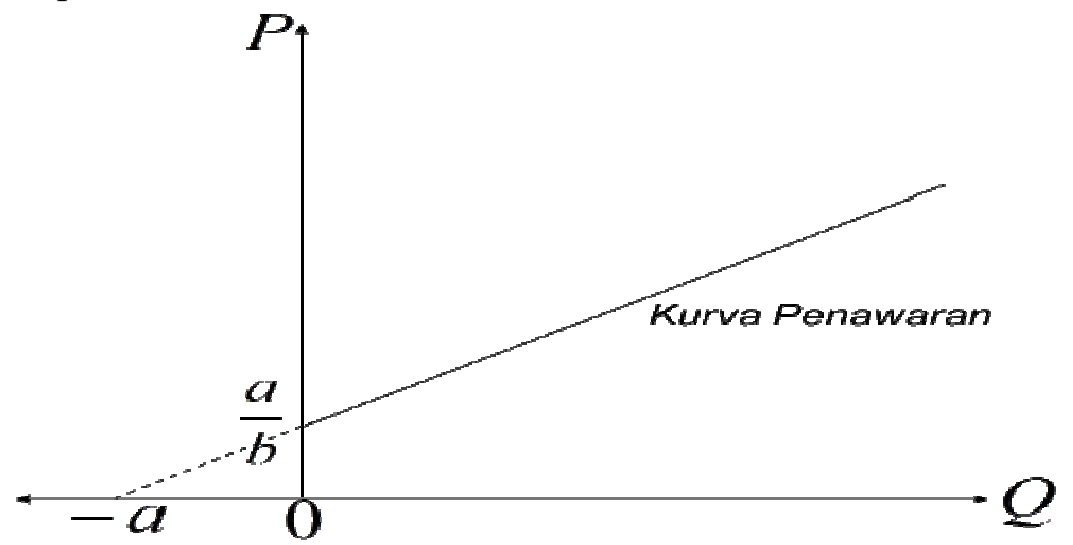

Gambar 2. Kurva Fungsi Linear Penawaran (Kalangi, 2015)

\section{Analisis Kesetimbangan Pasar}

Dalam Kalangi (2015), analisis kesetimbangan pasar merupakan kondisi yang terjadi karena interaksi antara fungsi permintaan dan fungsi penawaran sehingga diperoleh harga dan jumlah kesetimbangan pasar. Interaksi fungsi permintaan $Q_{d}=a-b P$ dan fungsi penawaran $Q_{s}=-c+d P$ dengan nilai semua parameter positif dan diasumsikan pada produk yang sama (satu macam produk), interaksi ini disebut dengan "Kesetimbangan Pasar satu macam produk". Pada penelitian ini, fungsi permintaan dan fungsi penawaran hanya memiliki satu variabel bebas sehingga analisis kesetimbangan pasar yang dilakukan adalah "Kesetimbangan Pasar satu macam produk".Kesetimbangan pasar yang terjadi dapat menciptakan harga dan jumlah keseimbangan di pasar. Teori ekonomi keseimbangan pasar memiliki syarat yaitu "jumlah produk yang diminta oleh konsumen harus sama dengan jumlah produk yang ditawarkan oleh produsen". Sehingga secara matematis dapat ditulis $Q_{d}=Q_{s}$ yaitu jumlah barang yang diminta samadengan jumlah barang yang ditawarkan. Ataupun harga produk yang diminta sama dengan harga produk yang ditawarkan, maka $P_{d}=P_{s}$. Secara matematis aljabar keseimbangan pasar dapat diperoleh dengan mengerjakan sistem persamaan linier antara fungsi permintaan dan fungsi penawaran secara serentak, yaitu cukup dengan menggunakan metode eliminasi ataupun subtitusi. Secara matematis 
geometri keseimbangan pasar yang terjadi ditunjukan oleh perpotongan antara kurva permintaan dan kurva penawaran, ditunjukan oleh Gambar 3.

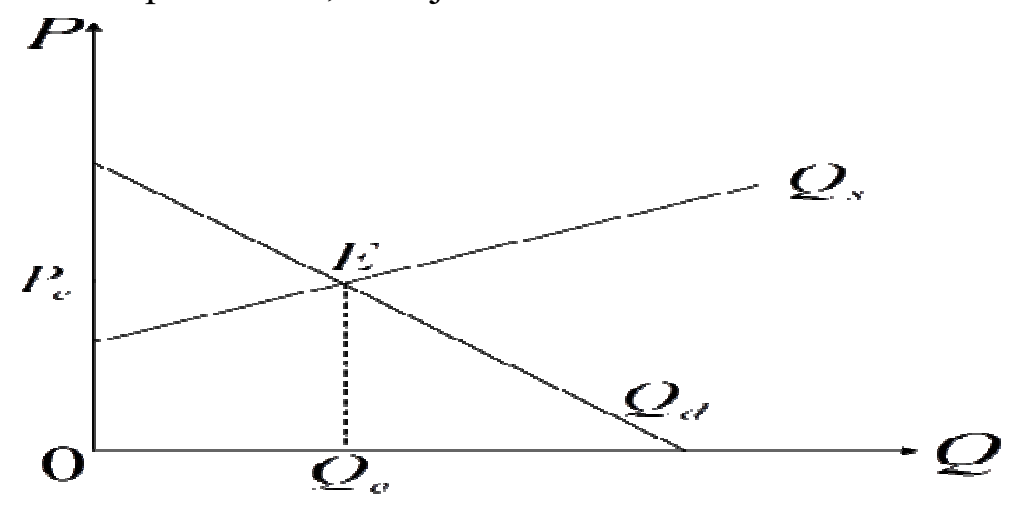

Gambar 3. Kurva Kesetimbangan Pasar

Teori keseimbangan pasar, perpotongan kurva permintaan dan kurva penawaran harus berada pada Kuadran I (satu) di bidang Cartesius karena harga maupun jumlah keseimbangan mempunyai nilai yang positif $(P, Q \geq 0)$. Bila terjadi perpotongan antara kurva permintaan dan penawaran bukan berada di Kuadran I maka secara ekonomi tidak mempunyai arti. Karena salah satu variabel bernilai negatif, sehingga fungsi linier yang ideal dari fungsi permintaan maupun penawaran harus memenuhi kriteria ekonomi tersebut. Dengan kata lain, analisis keseimbangan pasar satu produk menghasilkan jumlah keseimbangan dan harga keseimbangan yang postif. (Kalangi, 2015)

Model ekonomi fungsi permintaan maupun penawaran telah banyak dilakukan penelitian tentang itu, diantaranya oleh Bunyamin (2014), Yuliana, Halim dan Wahyudi (2002), menggunakan pendekatan model matematis untuk menentukan persentase markup harga jual suatu produk yang dirancang menggunakan statistik regresi berganda, kemudian Saragih, Melia dan Florenti J (2000) tentang Analisis factor-faktor yang mempengaruhi permintaan, Yusuf $M$ dan Muji Rahayu (2012) Analisis Permintaan Sayuran Dataran Tinggi Oleh Rumah Tangga di Kota Mataram serta Muqtadir Ahmad (2015) tentang analisis faktor-faktor yang mempengaruhi permintaan.Pada umumnya penelitian-penelitian tersebut diatas merupakan pembentukan maupun analisis model ekonomi permintaan ataupun penawaran dengan menggunakan pendekatan statistik analisis regresi tanpa melihat keidealan fungsi tidak dengan melakukukan analisis kesetimbangan pasar. Sehingga pada penelitian ini model ekonomi fungsi penawaran terebut dibentuk menjadi model matematis dari kumpulan data penawaran. Pembentukan model terssebut didekati dengan pendekatan matematis dan statistik kemudian akan ditentukan keidealannya jika terdapat sebuah fungsi permintaan. keidealan tersebut akan ditentukan dari analisis keetimbangan pasar.

\section{METODE PENELITIAN}

Penelitian ini akan dilakukan dengan pendekatan matematis dan studi literatur. Adapun kerangka analisis penelitian ini adalah :

1. Mencari persamaan-persamaan linear fungsi penawaran dari suatu data harga suatu barang/jasa (P) dan Jumlah (yang diminta/yang ditawarkan) dari barang/jasa tersebut, dengan cara :

Matematis: Metode Dwi-koordinat, Koordinat-gradien.

Statistika: Metode Regresi Linear. 
2. Menganalisis masing-masing persamaan linear fungsi-fungsi tersebut dengan analisis keseimbangan pasar secara Aljabar dan Geometri untuk melihat keidealan persamaan fungsi tersebut apakah sesuai dengan teori ekonomi permintaan/penawaran.

Objek pada penelitian ini adalah data penawaran yaitu harga barang/jasa (P) serta jumlah barang/jasa (Q) yang ditawarkan oleh produsen. Data $\mathrm{P}$ dan $\mathrm{Q}$ berupa data asumsi yang diberikan dengan berdasar pada kaidah ekonomi serta tunduk pada "Hukum Penawaran Suatu Barang/Jasa" yaitu: "Jika harga suatu barang/jasa naik (turun) (P), maka jumlah barang/jasa (Q) yang ditawarkan akan bertambah (berkurang)".Penyederhanaan data Penawaran suatu barang/jasa mengasumsikan hanya terdapat dua variabel yang berpengaruh yaitu P dan Q. Sehingga variabel yang lainnya diasumsikan konstan.Asumsi data penawaran tersebut disajikan dalam Tabel 1 berikut :

Tabel 1. Data Penawaran Harga dan Jumlah Barang

\begin{tabular}{cc}
\hline \hline HARGA $(\mathbf{P})$ & JUMLAH BARANG $(\mathbf{Q})$ \\
\hline \hline 1000 & 10 \\
3000 & 20 \\
5000 & 30 \\
7000 & 40 \\
10000 & 50 \\
\hline
\end{tabular}

Untuk validasi model atau penentuan keidealan fungsi penawaran yang terbentuk dengan melakukan analisis kesetimbangan pasar diperlukan sebuah fungsi permintaan. Maka, diasumsikan terdapat sebuah fungsi permintaan yang berbentuk persamaan linear yaitu yang berdasar pada hukum permintaan dalam teori ekonomi yaitu "Jika harga suatu barang/jasa naik (turun) (P), maka jumlah barang/jasa (Q) yang diminta akan berkurang (bertambah)". Secara matematis hukum permintaan tersebut menyatakan hubungan yang berbanding terbalik antar dua variabel. Hubungan fungsional tersebut secara geometri dapat dinyatakan dalam bentuk kurva permintaan yang memiliki gradien yang menurun karena parameter atau koofisien dari variabel bernilai negatif.Kesetimbangan pasar merupakan suatu kondisi setimbang antara penawaran dan permintaan. Kondisi ini akan dianalisis menggunakan prinsip serta aturan matematika aljabar dan geometri dan berdasarkan pada teori ekonomi hukum kesetimbangan.

Fokus penelitian ini adalah pembentukan model ekonomi fungsi penawaran dengan menggunakan metode-metode matematika dan statistika. Kemudian, dari model yang terbentuk tersebut akan ditentukan fungsi penawaran yang ideal yang berarti bahwa fungsi penawaran tersebut sesuai dengan prinsip serta teori ekonomi. Sehingga penelitian ini berfokus pada suatu metode, cara ataupun langkah-langkah dalam menentukan model matematika ekonomi khususnya fungsi penawaran apabila terdapat data penawaran yang sebenarnya dan diharapkan dari penelitian ini bisa menjadi alat atau instrument untuk mencari serta menentukan Model Ekonomi Fungsi Penawaran maupun fungsi permintaan yang ideal dengan berdasar pada teori ekonomi dan prinsip matematika. 


\section{HASIL DAN PEMBAHASAN}

Berdasarkan asumsi data penawaran dan dengan menggunakan metode-metode matematis diperoleh Model ekonomi fungsi penawaran yang disajikan dan dirangkum dalam Tabel 2 berikut.

Tabel 2. Model-model Ekonomi Fungsi Penawaran

\begin{tabular}{|c|c|c|}
\hline Nama Fungsi Linear & $\begin{array}{c}\text { Model Ekonomi } \\
\text { Fungsi Penawaran } \\
\end{array}$ & Metode pembentukan model \\
\hline FL1 & $Q=\frac{1}{200} P+5$ & \multirow{5}{*}{$\begin{array}{c}\text { METODE } \\
\text { DWI-KOORDINAT }\end{array}$} \\
\hline FL2 & $Q=\frac{4}{900} P+\frac{50}{9}$ & \\
\hline FL3 & $Q=\frac{3}{700} P+\frac{50}{7}$ & \\
\hline FL4 & $Q=\frac{2}{500} P+10$ & \\
\hline FL5 & $Q=\frac{1}{300} P+\frac{50}{3}$ & \\
\hline FL6 & $Q=\frac{1}{100} P$ & \multirow{5}{*}{$\begin{array}{c}\text { METODE } \\
\text { KOORDINAT-LERENG }\end{array}$} \\
\hline FL7 & $Q=\frac{1}{150} P$ & \\
\hline FL8 & $Q=\frac{3}{500} P$ & \\
\hline FL9 & $Q=\frac{1}{175} P$ & \\
\hline FL10 & $Q=\frac{1}{200} P$ & \\
\hline FL11 & $Q=\frac{11}{2440} P+30$ & $\begin{array}{c}\text { ANALISIS REGRESI LINEAR: } \\
\text { METODE KUADRAT } \\
\text { TERKECIL } \\
\end{array}$ \\
\hline
\end{tabular}

Dengan berdasarkan pada dua hal penting dalam fungsi penawaran, yaitu:

1. Parameter $b$ bernilai positif. Karena fungsi penawaran tunduk pada hukum penawaran, yaitu: "jika harga suatu produk naik (turun), maka jumlah produk yang ditawarkan oleh produsen akan bertambah (berkurang), dengan asumsi variabel lainnya adalah konstan".

2. Variabel bebas $P_{x}$ berpangkat 1 . Maka 11 model yang diperoleh dan dirangkum dalam Tabel 2 diatas dapat kita nyatakan sebagai model ekonomi fungsi penawaran yang berbentuk persamaan matematika persamaan garis lurus atau persamaan linear.

Maka 11 model dalam Tabel 2 diatas dapat dinyatakan sebagai Model Ekonomi Fungsi Penawaran. Namun, apakah model-model tersebut merupakan model ekonomi fungsi penawaran yang ideal?

Keidealan model ekonomi fungsi penawaran pada penelitian ini akan ditentukan dengan melakukan Analisis Kesetimbangan Pasar. Analisis ini menggunakan prinsipprinsip matematika aljabar dan geometri serta berdasar pada teori-teori ekonomi penawaran, permintaan, kesetimbangan pasar. 
Berikut ini diberikan beberapa referensi teori ekonomi yang akan digunakan dalam analisis kesetimbangan pasar.

1. Kesetimbangan pasar merupakan suatu keadaan dimana pada suatu tingkat harga tertentu, keinginan pembeli untuk mendapatkan barang sama dengan keinginan penjual dalam menawarkan barangnya. (Sadono S, 2010)

2. Pasar berada dalam keadaan kesetimbangan pasar apabila tercapai jumlah output yang diminta sama dengan yang ditawarkan. Pasar satu macam barang dikatakan dalam keadaan setimbang apabila jumlah yang diminta pasar tersebut sama dengan jumlah barang yang ditawarkan. Jika pada harga tertentu jumlah permintaan dan jumlah penawaran sama maka harga pasar tersebut merupakan harga kesetimbangan. (Rosidi S, 2012)

Sehingga, untuk menentukan titik keseimbangan pasar untuk suatu barang atau jasa, perlu diperhatikan syarat-syarat yang harus dipenuhi. Syarat-syarat titik kesetimbangan pasar adalah: a) Titik keseimbangan pasar hanya berlaku untuk nilainilai positif, b) Titik keseimbangan pasar hanya berlaku titik yang memenuhi ketentuan bagi kurva permintaan dan kurva penawaran.

Dari syarat titik kesetimbangan pasar diatas, maka tidak akan ada dua titik keseimbangan pasar bagi suatu kurva permintaan dan kurva penawaran. Walaupun mungkin terdapat dua titik potong dari fungsi permintaan dan penawaran. (Utomo J, 2014)

Maka, secara matematis analisis kesetimbangan pasar adalah sebagai berikut.

1. Secara aljabar, kondisi kesetimbangan yang terjadi dapat dituliskan dalam bentuk

$$
Q_{\text {Penawaran }}=Q_{\text {Permintaan }} \Leftrightarrow a+b P_{\text {Penawaran }}=a-b P_{\text {Permintaan }}
$$

dengan menggunakan metode subtitusi dan eliminasi akan diperoleh harga kesetimbangan $\left(P_{E}\right)$ dan jumlah kesetimbangan $\left(Q_{E}\right)$.

2. Secara geometri, kesetimbangan pasar adalah kondisi dimana terjadinya perpotongan antara kurva penawaran dan kurva permintaan. Perpotongan antara kedua kurva tersebut akan menghasilkan pasangan titik koordinat variabel bebas dan variabel takbebas yang secara ekonomi koordinat tersebut menyatakan nilai Harga kesetimbangan $\left(P_{E}\right)$ dan jumlah kesetimbangan $\left(Q_{E}\right)$. Kondisi ini harus berada dalam Kuadran I bidang Cartesius, dimana nilai harga kesetimbangan dan jumlah kesetimbangan bernilai tak-negatif. Sehingga bila terjadi perpotongan kurva penawaran dan permintaan diluar Kuadran I akan menyebabkan salah satu atau kedua nilai variabel P dan Q akan bernilai negatif. Mengakibatkan model ekonomi tersebut bukanlah model ekonomi yang ideal.

3. Selain itu, diperlukan sebuah fungsi permintaan dalam melakukan analisis kesetimbangan pasar. Sehingga, asumsi Fungsi permintaan pada penelitian ini adalah:

$$
Q_{d}=-\frac{1}{150} P_{d}+\frac{100}{15}
$$

Hasil analisis kesetimbangan pasar pada penelitian disajikan dalam Tabel 3 berikut. 
Tabel 3. Model Ekonomi Fungsi Penawaran yang Ideal

\begin{tabular}{|c|c|c|c|c|}
\hline $\begin{array}{l}\text { Fungsi } \\
\text { Linear }\end{array}$ & $\begin{array}{c}\text { Model Ekonomi } \\
\text { Fungsi Penawaran }\end{array}$ & $\begin{array}{c}\text { Harga dan Jumlah } \\
\text { Kesetimbangan }\end{array}$ & $\begin{array}{c}\text { Ideal/ Tidak } \\
\text { Ideal }\end{array}$ & Metode \\
\hline FL1 & $Q=\frac{1}{200} P+5$ & $\begin{array}{l}P_{E}=+142,8571 \\
Q_{E}=+5,714\end{array}$ & Ideal & \multirow{5}{*}{$\begin{array}{c}\text { METODE } \\
\text { DWI- } \\
\text { KOORDINAT }\end{array}$} \\
\hline FL2 & $Q=\frac{4}{900} P+\frac{50}{9}$ & $\begin{array}{l}P_{E}=+100 \\
Q_{E}=+6\end{array}$ & Ideal & \\
\hline FL3 & $Q=\frac{3}{700} P+\frac{50}{7}$ & $\begin{array}{l}P_{E}=-43,4782 \\
Q_{E}=+6,956\end{array}$ & Tidak Ideal & \\
\hline FL4 & $Q=\frac{2}{500} P+10$ & $\begin{array}{l}P_{E}=-312,5 \\
Q_{E}=+8,75\end{array}$ & Tidak Ideal & \\
\hline FL5 & $Q=\frac{1}{300} P+\frac{50}{3}$ & $\begin{array}{l}P_{E}=-1000 \\
Q_{E}=+13,3333\end{array}$ & Tidak Ideal & \\
\hline FL6 & $Q=\frac{1}{100} P$ & $\begin{array}{l}P_{E}=+400 \\
Q_{E}=+4\end{array}$ & Ideal & \multirow{5}{*}{$\begin{array}{c}\text { METODE } \\
\text { KOORDINAT- } \\
\text { LERENG/GRADI } \\
\text { EN }\end{array}$} \\
\hline FL7 & $Q=\frac{1}{150} P$ & $\begin{array}{l}P_{E}=+500 \\
Q_{E}=+5\end{array}$ & Ideal & \\
\hline FL8 & $Q=\frac{3}{500} P$ & $\begin{array}{l}P_{E}=+526,316 \\
Q_{E}=+3,158\end{array}$ & Ideal & \\
\hline FL9 & $Q=\frac{1}{175} P$ & $\begin{array}{l}P_{E}=+538,4615 \\
Q_{E}=+3,077\end{array}$ & Ideal & \\
\hline FL10 & $Q=\frac{1}{200} P$ & $\begin{array}{l}P_{E}=+571,428571 \\
Q_{E}=+2,8571\end{array}$ & Ideal & \\
\hline FL11 & $Q=\frac{11}{2440} P+30$ & $\begin{array}{l}P_{E}=-2088,02 \\
Q_{E}=+20,5868\end{array}$ & Tidak Ideal & $\begin{array}{l}\text { ANALISIS } \\
\text { REGRESI } \\
\text { LINEAR: } \\
\text { METODE } \\
\text { KUADRAT } \\
\text { TERKECIL }\end{array}$ \\
\hline
\end{tabular}

Dari Tabel 3 diatas, 11 model fungsi penawaran yang terbentuk secara matematis statistika tidak semuanya ideal. 7 fungsi penawaran merupakan fungsi yang ideal secara matematis dan berdasar pada kaidah-kaidah ekonomi penawaran, permintaan dan kesetimbangan pasar. Dengan menggunakan metode Dwi-Koordinat diperoleh lima jenis fungsi penawaran yang berbeda nilai parameter $a$ dan $b$. Fungsi-fungsi tersebut diperoleh dengan mengambil kombinasi 2 titik koordinat dari 5 pasang titik koordinat yang ada pada Tabel 2. Dengan analisis kesetimbangan pasar yang dilakukan 5 fungsi penawaran yang terbentuk dengan metode ini diperoleh 3 fungsi penawaran yang ideal jika diketahui fungsi permintaan $Q_{D}=\frac{100}{15}-\frac{1}{150} P_{d}$. Dengan menggunakan metode Koordinat-Lereng/Gradien diperoleh lima jenis fungsi penawaran yang berbeda nilai parameter $\mathrm{b}$ namun nilai dari parameter a adalah sama dengan nol. Fungsi-fungsi 
tersebut diperoleh dengan mengambil kombinasi 1 titik koordinat dan koordinat titik asal. Masing-masing kombinasi tersebut akan membentuk kemiringan/gradien yang berbeda-beda. Karena dengan metode ini pembentukan model fungsi penawaran yang dilakukan akan sama halnya jika dilakukan menggunakan metode Dwi-Koordinat dengan pasangan titik koordinat OA, OB, OC, OD dan OE. Dengan analisis kesetimbangan pasar yang dilakukan 5 fungsi penawaran yang terbentuk kesemuanya adalah fungsi penawaran yang ideal jika diketahui fungsi permintaan $Q_{D}=\frac{100}{15}-\frac{1}{150} P_{d}$. Dengan metode kuadrat terkecil dalam analisis regresi diperoleh 1 jenis fungsi penawaran yang tidak ideal. Fungsi penawaran tersebut adalah $Q=\frac{11}{2440} P+30$.

Telah dibentuk model ekonomi fungsi penawaran berdasarkan asumsi data penawaran yang diberikan pada Tabel 2 dan dari 11 fungsi penawaran tersebut diperoleh 8 fungsi penawaran yang ideal jika diketahui atau diberikan asumsi fungsi permintaan $Q_{D}=\frac{100}{15}-\frac{1}{150} P_{d}$ dengan melakukan analisis kesetimbangan pasar. 11 fungsi penawaran tersebut merupakan model ekonomi matematika yang berbentuk persamaan linear yang dibentuk secara matematis dengan menggunakan 3 metode yaitu Dwi-Koordinat, Koordinat-Lereng dan Metode Kuadrat terkecil dalam analisis regresi linear sederhana. 11 fungsi penawaran tersebut keidealannya berdasarkan asumsi fungsi permintaan yang diberikan. Fungsi permintaan dalam penelitian ini adalah fungsi asumsi dan digunakan untuk melakukan analisis kesetimbangan pasar dengan maksud untuk menentukan fungsi mana yang ideal dari 11 fungsi penawaran yang terbentuk. Fungsi permintaan tersebut langsung diberikan atau diasumsikan dalam bentuk sebuah persamaan linear. Akan berbeda halnya jika fungsi permintaan dibentuk kumpulan data permintaan $\mathrm{P}$ dan Q. Dilain pihak, asumsi data penawaran pada Tabel 2 bisa diassumsikan menjadi kumpulan data permintaan yang menyatakan hubungan variabel $\mathrm{P}$ dan $\mathrm{Q}$ adalah berbanding terbalik. Sehingga dapat kita nyatakan kumpulan data permintaan berdasarkan data penawaran sebagai berikut.

Tabel 4. Data Penawaran dan Permintaan

\begin{tabular}{ccc}
\hline \hline HARGA $(\mathbf{P})$ & PENAWARAN & PERMINTAAN \\
\hline \hline 1000 & 10 & 50 \\
3000 & 20 & 40 \\
5000 & 30 & 30 \\
7000 & 40 & 20 \\
10000 & 50 & 10 \\
\hline \hline
\end{tabular}

Tabel 4 diatas merupakan asumsi kumpulan data penawaran dan permintaan dengan memperhatikan hubungan variabel $\mathrm{P}$ dan $\mathrm{Q}$. Jika dalam data penawaran hubungan fungsional antara variabel $\mathrm{P}$ dan $\mathrm{Q}$ berbanding lurus maka asumsi hubungan variabel $\mathrm{P}$ dan $\mathrm{Q}$ pada kumpulan data permintaan adalah sebaliknya yaitu berbanding terbalik. Sehingga, dengan cara yang sama menggunakan metode matematis seperti dalam pembentukan fungsi penawaran maka akan diperoleh 11 fungsi permintaan yang 
berbeda-beda juga seperti pada fungsi penawaran yaitu diperoleh 11 fungsi penawaran dan 11 fungsi permintaan yang belum tentu ideal. Jika terdapat 11 fungsi permintaan dan 11 fungsi penawaran maka penentuan fungsi yang ideal bisa namun akan sulit kita tentukan karena banyak kombinasi fungsi penawaran dan fungsi permintaan yang diperlukan untuk melakukan analisis kesetimbangan pasar dalam penentuan fungsi yang ideal. Karena untuk melihat dan menentukan keidealan suatu fungsi penawaran maupun fungsi permintaan diperlukan sebuah asumsi lagi yaitu salah satu fungsi diketahui adalah fungsi yang sudah ideal. Misalkan akan ditentukan fungsi penawaran yang ideal dengan melakukan analisis kesetimbangan pasar, maka kita harus menambah asumsi bahwa fungsi-fungsi permintaan yang terbentuk adalah sudah ideal, begitu juga sebaliknya. Jika hal tersebut dilakukan, maka akan terdapat $11 \times 11=121$ kombinasi yang berbeda untuk menentukan fungsi penawaran yang ideal. Begitu juga dengan penentuan fungsi permintaan yang ideal. Sehingga jumlah kombinasi analisis kesetimbangan pasar untuk menentukan fungsi penawaran dan fungsi permintaan yang ideal adalah 242 dengan asumsi terdapat 11 fungsi penawaran dan 11 fungsi permintaan, penentuan fungsi penawaran yang ideal mengasumsikan 11 fungsi permintaan adalah fungsi ideal begitu juga dalam penentuan fungsi permintaan yang ideal dibuat asumsi bahwa 11 fungsi penawaran terebut sudah ideal. Metode Dwi Koordinat yang memperoleh 5 jenis fungsi penawaran diperoleh fungsi penawaran yang ideal jika diketahui fungsi permintaan $Q_{D}=\frac{100}{15}-\frac{1}{150} P_{d}$. Sedangakan fungsi yang dibentuk dengan metode Koordinat-Lereng, kelima fungsi tersebut erupakan fungsi yang ideal. Lain halnya ketika fungsi penawaran yang dibentuk dengan metode kuadrat terkecil analisis regresi linear sederhana diperoleh sebuah fungsi penawaran yang tidak ideal. Penentuan atau penaksiran fungsi penawaran yang berkaitan dengan cara memperoleh nilai-nilai parameter pada fungsi penawaran yang ideal. Fungsi penawaraan ideal harusnya diarahkan untuk memilah sampel random yang cukup mencerminkan pasar sasaran, dan ukuran masing-masing sampel harus cukup besar sehingga model tersebut dapat dipercaya. Selanjutnya pengambilan data sampel penawaran harus didisain sehingga dalam melakukan analisa regresi dari data yang dikumpulkan memungkinkan perhitungan koefisien-koefisien fungsi penawaran yang menunjukkan keyakinan yang bisa digunakan untuk mendapatkan taksiran nilai parameter. Sehingga perlu dikaji lagi dengan menggunakan metode statistika yang lebih mendalam. Dalam hal ini, perlu dilakukan analisis terhadap data penawaran dengan melihat pola hubungan, korelasi serta perlu dilakukan uji bersamaan, parsial maupun residu dari model linear yang terbentuk.

\section{E. PENUTUP}

Berdasarkan hasil dan pembahasan diperoleh sebelas fungsi penawaran yang terbentuk dengan menggunakan metode matematis dwi-koordinat, koordinat-lereng dan metode kuadrat terkecil dalam analisis regrei linear sederhana jika diketahui atau diberikan kumpulan data penawaran. Kemudian dengan melakukan analisis kesetimbangan pasar dengan mengasumsikan atau diberikan sebuah fungsi permintaan yang ideal diperoleh:

Dengan menggunakan metode Dwi-Koordinat diperoleh 5 jenis fungsi penawaran yang berbeda nilai parameter a dan b. Fungsi-fungsi tersebut diperoleh dengan mengambil kombinasi 2 titik koordinat dari 5 pasang titik koordinat yang ada pada Tabel 2. Dengan analisis kesetimbangan pasar yang dilakukan 5 fungsi penawaran yang 
terbentuk dengan metode ini diperoleh 2 fungsi penawaran yang ideal.Dengan menggunakan metode Koordinat-Lereng/Gradien diperoleh 5 jenis fungsi penawaran yang berbeda nilai parameter $b$ namun nilai dari parameter a adalah sama dengan nol. Fungsi-fungsi tersebut diperoleh dengan mengambil kombinasi 1 titik koordinat dan koordinat titik asal. Masing-masing kombinasi tersebut akan membentuk kemiringan/gradien yang berbeda-beda. Karena dengan metode ini pembentukan model fungsi penawaran yang dilakukan akan sama halnya jika dilakukan menggunakan metode Dwi-Koordinat dengan pasangan titik koordinat OA, OB, OC, OD dan OE. Dengan analisis kesetimbangan pasar yang dilakukan 5 fungsi penawaran yang terbentuk kesemuanya adalah fungsi penawaran yang ideal.Dengan metode kuadrat terkecil dalam analisis regresi diperoleh 1 jenis fungsi penawaran yang tidak ideal. Fungsi penawaran tersebut adalah: $Q=\frac{11}{2440} P+30$.Keidealan fungsi yang dibentuk dengan metode-metode matematis pada penelitian ini hanya menggunakan analisis yang sederhana saja. Sehingga perlu dikaji lagi dengan menggunakan analisis yang lebih mendalam misalkan metode statistika yang lebih mendalam dengan melihat sebaran data pola hubungan, korelasi yang perlu dilakukan uji bersamaan, uji parsial maupun residu dari model linear yang terbentuk.

\section{DAFTAR PUSTAKA}

Adilah, A. Bunyamin. 2014. Analisis Pengaruh Permintaan Kredit Terhadap Pertumbuhan Ekonomi Di Indonesia Periode 2000-2013. Fakultas Ekonomi Universitas Hasanuddin, Makassar.

Dumairy., 2015. Matematika Terapan untuk Bisnis dan Ekonomi Ed.2.Fakultas Ekonomi dan Bisnis UGM.BPFE-Yogyakarta. Cetakan ke-8

Joko Utomo. 2014. Matematika Ekonomi dan Bisnis. Kudus : BPFE-UMK.

Kalangi, JB., 2015. Matematika Ekonomi dan Bisnis (Edisi 3 Buku 1). Salemba4 Jakarta ISBN 978-979-061-542-7

Muqtadir, Ahmad. 2015. Analisis Faktor-Faktor Yang Mempengaruhi PermintaanJasa Angkutan Kota Di Kabupaten Pangkep. Fakultas Ekonomi UniversitasHasanuddin, Makassar.

Purbowati, R., \& Utomo, L. P. (2016). FAKTOR-FAKTOR YANG MEMPENGARUHI PADA PENERIMAAN OPINI DENGAN PARAGRAF PENJELAS GOING CONCERN. Eksis: Jurnal Riset Ekonomi dan Bisnis, 11(1).

Rosidi A, Syamsianah A. 2012. Optimalisasi Perkembangan Motorik Kasar dan Ukuran Anthropometri Anak Balita di Posyandu "Balitaku Sayang" Kelurahan Jangli Kecamatan Tembalang Kota Semarang. Seminar Hasil-Hasil Penelitian - LPPM UNIMUS 2012. http://jurnal.unimus.ac.id/index.php/psn12012010/article/view/508/557 Diakses Maret 2016.

Sadono, Sukirno. 2010. Makroekonomi. Teori Pengantar. Edisi Ketiga. PT. RajaGrasindo Perseda. Jakarta

Saragih, Melia, Florenti J. 2000. Analisis factor-faktor yang mempengaruhipermintaan mobil Toyota Kijang pada PT. ASTRA INTERNASIONAL AUTO2000. Universitas Sumatra Utara. Medan.

Yuliana., Wahyudi., Halim., 2002. Pendekatan model matematis untuk menentukan presentasi MURKUP harga jual produk. Jurnal keilmuan dan aplikasi Teknik Industri. Vol.4 No.2 ISSN:2087-7439. Hal.58-72

Yusuf, M., Muji Rahayu, 2012. “Analisis Permintaan Sayuran Dataran Tinggi Oleh Rumah Tangga di Kota Mataram", Volume 6 Nomor 2 